\title{
REMEDIASI ELEKTROKINETIK TERHADAP LOGAM-LOGAM BERAT MENGGUNAKAN ELEKTRODA 2-D HEXAGONAL PADA TANAH DARI TEMPAT PEMBUANGAN AKHIR (TPA) TOISAPU AMBON
}

\author{
Noke Kesaulya ${ }^{1}$, Yuli T. Filindity ${ }^{2}$ \\ ${ }^{1}$ Program Studi Pendidikan Fisika, Jurusan Pendidikan MIPA FKIP Unpatti \\ ${ }^{2}$ Program Studi Pendidikan Kimia, Jurusan Pendidikan MIPA FKIP Unpatti
}

Diterima 08 Maret 2019/Disetujui 15 April 2019

\begin{abstract}
The Electrokinetic Remediation process for soil using 2-D hexagonal electrode has been done with observing $\mathrm{pH}$ and concentration of heavy metals, such as $\mathrm{Hg}, \mathrm{Zn}$ and $\mathrm{Pb}$ of soil before, during and after processing the electrokinetic. Results of research indicated that contents of soil in $\mathrm{Hg}$ metal ions were $1.088 \mathrm{ppm} ; \mathrm{Zn}=0.135$ ppm and $\mathrm{Pb}, 0.115 \mathrm{ppm}$. Concentration of the metal ions was different to each time because rubbish in TPA was also different. Process efficiencies for $\mathrm{Hg}$ were $24.78 \%$; $\mathrm{Zn}, 33.71 \%$ and $\mathrm{Pb}, 10.13 \%$. Efficiency process of electrokinetic remediation was highly influence by distance of cathode and duration of remediation process. Closer distance from cathode, time taken for remediation process was shorter, also the opposite.
\end{abstract}

Keywords : Soil, heavy metal, electrokinetic remediation, 2-D hexagonal electrode.

\begin{abstract}
ABSTRAK
Telah dilakukan proses remediasi elektrokinetik pada tanah menggunakan elektroda 2-D hexagonal dengan pengamatan terhadap $\mathrm{pH}$ dan konsentrasi logam berat seperti $\mathrm{Hg}$, $\mathrm{Zn}$ dan $\mathrm{Pb}$ dalam tanah sebelum proses, selama proses dan setelah proses elektrokinetik telah dilakukan. Hasil penelitian memperlihatkan bahwa kandungan dalam tanah terkandung ion logam merkuri $(\mathrm{Hg})$ sebesar 1,088 ppb, Seng (Zn) sebesar 0,135 ppm dan Timbal $(\mathrm{Pb})$ sebesar $0,115 \mathrm{ppm}$. Tetapi konsentrasi ion-ion logam tersebut tidak sama untuk tiap waktu karena sampah yang terdapat di TPA juga berbeda. Efisiensi proses untuk Merkuri sebesar 24,78 \%, Seng 33,71 $\%$ dan Timbal 10,13\%. Efisiensi proses remediasi elektrokinetik sangat dipengaruhi oleh jarak dari katoda dan lamanya proses remediasi. Semakin dekat jarak dengan katoda, waktu yang diperlukan untuk proses remediasi semakin singkat, demikian sebaliknya
\end{abstract}

Kata kunci : Tanah, logam berat, remediasi elektrokinetik, elektroda 2-D hexagonal.

\section{PENDAHULUAN}

Pertumbuhan kota dengan perkembangan industri tidak hanya menyebabkan peningkatan kesejahteraan masyarakat, tetapi juga menimbulkan berbagai masalah baru yakni yang terkait dengan pencemaran lingkungan oleh limbah-limbah buangan industri dan terutama oleh sampah yang semakin meningkat dari waktu ke waktu.

Tiap-tiap kota memiliki wilayah khusus yang dijadikan sebagai Tempat Pembuangan Akhir (TPA), demikian halnya dengan kota Ambon. PEMDA kota Ambon menetapkan lahan seluas $3-5$ Ha di dusun Toisapu, Desa Hutumuri, Kecamatan Leitimur Selatan Kodya Ambon sebagai salah satu TPA. TPA Toisapu ini, setiap harinya menerima 50 - 100 ton sampah asal Kota Ambon dan sekitarnya.

Timbunan sampah di TPA Toisapu perlu ditangani serius karena dengan jumlah sampah yang masuk sedemikian besar setiap harinya akan dapat menurunkan kualitas lingkungan di TPA juga di 
sekitar TPA tersebut yang disebabkan karena tumpukan-tumpukan sampah menghasilkan barbagai limbah berupa gas berbau busuk, padatan yang tidak dapat terurai di tanah, juga limbah cair (leachate) yang mencemari air tanah dan sungai serta timbunan sampah dapat menjadi sumber penyakit.

Tanah merupakan salah satu medium alami untuk pertumbuhan dan perkembangan mikroorganisme yang tersusun dari bahan organik dan anorganik. Kemampuan mikroorganisme dalam menguraikan bahan organik dan anorganik menjadi senyawa yang lebih sederhana (proses respirasi), selain ditentukan oleh jumlah dan jenis mikroorganisme tanah juga ditentukan oleh kondisi kimiawi tanah. Adanya bahan pencemar berupa logam berat dalam tanah yang bersifat toksik misalnya $\mathrm{Hg}$, pada konsentrasi tertentu dapat menghambat pertumbuhan dan aktifitas respirasi mikroorganisme (Parizek, 1978). Selain itu logam-logam berat di tanah mengalami transport mengikuti aliran air tanah menyebar ke tempat yang lebih rendah dalam waktu yang lama sehingga dapat mencemari air tanah. Dengan melihat begitu banyak jenis sampah yang terbuang di TPA Toisapu, maka kemungkinan tanah yang terdapat disana juga mengandung ion-ion logam berat seperti $\mathrm{Hg}, \mathrm{Cu}, \mathrm{Pb}, \mathrm{Cr}$ dan lain sebagainya. Walaupun pada konsentrasi yang rendah efek ion logam berat dapat berpengaruh terhadap kesehatan manusia dimana logam berat memiliki sifat yang akumulatif di dalam tubuh yang akan menyebabkan kerusakan pada otak, syaraf, jantung, hati dan ginjal.

Untuk mengeliminasi kehadiran logam-logam berat dalam tanah, salah satu upaya yang dapat ditempuh adalah dengan cara pemulihan (remediasi) tanah. Pemulihan tanah secara elektrokinetik merupakan salah satu upaya pemulihan tanah yang tercemar oleh logam berat dari kontaminan organik lainnya secara in situ. Teknologi remediasi tersebut dalam penerapannya menggunakan biaya yang rendah dan sangat potensial digunakan untuk berbagai tipe kontaminan.

Dengan demikian maka penting untuk mengidentifikasi unsur logam berat yang terkandung dalam tanah yang diperoleh dari TPA Toisapu, mengetahui efisiensi penurunan konsentrasi logamlogam berat pada tanah menggunakan remediasi elektrokinetik dengan konfigurasi 2-D hexagonal dan perlu diketahui seberapa besar pengaruh waktu dan jarak terhadap penurunan kadar tiap logam berat dalam proses remediasi elektrokinetik menggunakan konfigurasi 2-D hexagonal.

Remediasi adalah pemulihan pada suatu media yang terkontaminasi oleh zat-zat pencemar seperti logam berat dan atau senyawa organik untuk mengembalikan fungsi dari media tersebut sehingga dapat dimanfaatkan kembali dan tidak menimbulkan masalah.

Remediasi secara elektrokinetik merupakan teknologi pemulihan lumpur (sludge) tercemar logam berat dan senyawa-senyawa organik melalui proses secara in-situ dengan menggunakan tegangan listrik rendah dan arus DC (direct current) pada potongan melintang area antar elektroda yang diletakkan pada tanah dengan susunan aliran terbuka. Tekanan aliran pada umumnya digolongkan dalam miliampere per sentimeter kuadrat $\left(\mathrm{mA} / \mathrm{cm}^{2}\right)$ atau beda potensial tegangan listrik volt per sentimeter.

Dengan penerapan teknologi remediasi tersebut diharapkan kontaminan logam berat dalam media dapat dipindahkan/digerakkan, dipekatkan/dipadatkan, oleh elektroda serta diekstraksikan dari tanah, yang secara skematik dapat dilihat pada gambar 1 (Alshawabkeh, 2001). 


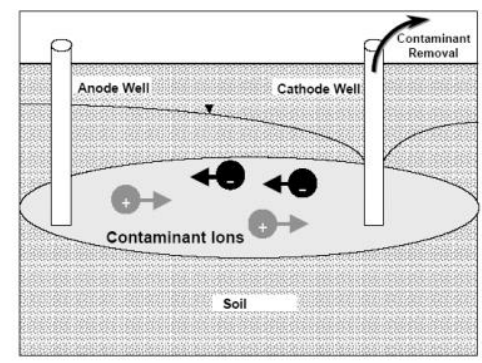

Gambar 1. Prinsip dasar remediasi elektrokinetik. Sumber: Alshawabkeh, 2001

Pada teknologi remediasi, elektroda ditempatkan pada media secara vertikal maupun horizontal. Ketika arus searah (direct current) (DC) digunakan pada elektroda, dihasilkan media yang terpengaruhi medan listrik oleh katoda dan anoda. Pengunaan sistem tersebut pada cairan mempunyai efek elektrolisis air.

Ion dan molekul kutub dalam pori-pori cairan berpindah di bawah medan listrik. Di bawah medan listrik kation atau ion logam akan bergerak menuju katoda sedangkan anion bergerak menuju anoda dalam arah yang berbeda dipengaruhi oleh muatan listrik dan materi psikokimia. Salah satu aspek yang penting dari pengolahan media secara elektrolisis adalah perpindahan asam dari anoda ke katoda selama pengolahan.Ketika elektrolisis terjadi di permukaan elektroda, ion-ion hidrogen diproduksi di anoda dan ion-ion hidroksil di katoda. Elektrolisis air yang terjadi dalam katoda adalah sebagai berikut :

Dalam anoda : $2 \mathrm{H}_{2} \mathrm{O} \rightarrow 4 \mathrm{H}+\mathrm{O}_{2}(\mathrm{~g})+4 \mathrm{e}^{-}$

Dalam katoda : $2 \mathrm{H}_{2} \mathrm{O}+2 \mathrm{e}^{-} \rightarrow 2 \mathrm{OH}^{-}+\mathrm{H}_{2}(\mathrm{~g})$

Hasil dari elektrolisis adalah asam di anoda dan alkali di katoda yang terjadi secara terpisah. Pergerakan asam dan basa meningkatkan ion logam di dekat anoda dan penggumpalan ion logam di dekat katoda. Kondisi ini secara signifikan mempengaruhi $\mathrm{pH}$ dan kekuatan pori-pori ion air dan mobilitas serta daya larut logam pencemar dan kondisi muatan dari partikel media. Variasi pH di media dengan elektrolisis air pada daerah sekitar elektroda memberikan efek kekuatan partikel air dan karateristik permukaan merupakan seperti kapasitas kation, magnitudo dan zeta potensial. Selanjutnya spesifikasi mobilitas, daya larut dari kontaminan sering divariasikan dengan $\mathrm{pH}$ dalam media selama pengolahan, yang mana dapat membatasi atau meningkatkan efisiensi pengolahan.

Material elektroda, bahan kimia yang tidak bereaksi dan bahan yang bisa menghantarkan arus listrik seperti platinum, grafit dan coated titanium bisa digunakan sebagai anoda untuk menahan dissolusi elektroda dan berlangsungnya pengkaratan dalan kondisi asam. Material elektroda yang digunakan dalam penelitian ini adalah elektroda stainless steel dengan panjang $\pm 25 \mathrm{~cm}$, sedangkan dimensi reaktor $1 \mathrm{~m} \times 1 \mathrm{~m} \times 0.60 \mathrm{~m}$.

Konfigurasi elektroda yang digunakan dalam penelitian ini yaitu elektroda 2-D hexagonal terdiri dari beberapa sel, masing-masing berisi satu katoda yang dikelilingi oleh 6 kutub positif (anoda). Elektroda adalah logam yang dapat menerima ion-ion atau menyerahkan ion dimana logam tercelup di dalam suatu larutan elektrolit. Sel yang bila dialiri arus listrik akan menghasilkan reaksi kimia, yaitu akan merubah energi listrik menjadi reaksi kimia disebut elektrolisis. Pada kutub anoda akan terjadi reaksi oksidasi dan pada kutub katoda terjadi reaksi reduksi (Johannes, 1978). 


\section{METODE PENELITIAN}

Penelitian ini dilaksanakan di Laboratorium Pendidikan Fisika dan Kimia Fakultas Keguruan dan IImu Pendidikan Universitas Pattimura Ambon. Metode yang digunakan dalam penelitian ini adalah metode eksperimen di laboratorium. Pada penelitian ini dilakukan penerapan metode Remediasi elektrokinetik.

Sampel tanah diambil dari TPA Toisapu sebanyak $0,25 \mathrm{~m}^{3}$ yang dimasukkan kedalam 10 karung $25 \mathrm{Kg}$. Setelah sampai di laboratorium dimasukan ke dalam wadah kaca dengan ukuran $\mathrm{P} \times \mathrm{L} \times \mathrm{T}$ $=1 \mathrm{~m} \times 1 \mathrm{~m} \times 0,25 \mathrm{~cm}$. Digunakan elektroda karbon berbentuk silinder. Seluruh permukaan elektroda ditancapkan kedalam sampel tanah secara vertikal dengan jarak antar elektroda $40 \mathrm{~cm}$ dengan menggunakan konfigurasi 2-D hexagonal. Kebutuhan elektroda : Konfigurasi elektroda hexagonal terdiri dari beberapa sel, masing-masing berisi satu katoda yang dikelilingi oleh 6 kutub positif (anoda), seperti pada Gambar 2.

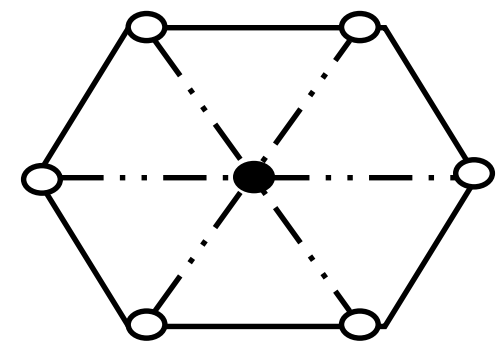

Gambar 2. Konfigurasi 2-D hexagonal

Digunakan power supply 24 volt dan 0,5 A DC, kabel power supply dihubungkan ke konektor pada elektroda. Dilakukan sample leachate pada setiap titik sampling dengan rentang waktu setiap 3 jam (untuk pengamatan ini arus listrik dimatikan).

\section{Parameter yang diukur}

a. Area pengukuran konsentrasi logam-logam berat.

b. Pengukuran konsentrasi logam-logam berat pada tiap waktu pengamatan disetiap tiap area pengambilan sampel yang telah ditetapkan menggunakan AAS (Atomic Absorption Spektrometry).

c. Pengukuran resistensi pada tiap waktu pengamatan.

d. Untuk menentukan efisiensi penurunan konsentrasi tiap ion logam berat pada tanah setelah dilakukan remediasi secara elektrokinetik adalah dengan menggunakan persamaan sebagai berikut : (Metcalf and Eddy, 1999)

$$
E=\frac{C_{a w a l}-C_{a k h i r}}{C_{a w a l}} \times 100 \%
$$

$$
\begin{aligned}
& \text { Keterangan : } \quad E=\text { Effisiensi }(\%) \\
& C=\text { Konsentrasi }
\end{aligned}
$$




\section{HASIL PENELITIAN}

Hasil pengamatan secara visual pada lokasi TPA Toisapu terdapat beberapa timbunan sampah yang menyebar pada lokasi TPA. Sampel awal diambil pada daerah tengah timbunan-timbunan sampah tersebut demikian juga untuk sample untuk proses remediasi elektrokinetik. Hasil Analisis sampel awal dapat dilihat pada Tabel 1.

Tabel 1. Jenis Logam Berat dan Konsentrasinya dalam Tanah dari TPA Toisapu Ambon.

\begin{tabular}{|c|l|c|c|}
\hline No & Jenis Logam Berat & Konsentrasi $^{*}$ ) & $\left.\begin{array}{c}\text { Kadar Maksimum yang } \\
\text { diperbolehkan }\end{array}{ }^{* *}\right)$ \\
\hline 1. & Merkuri $(\mathrm{Hg})$ & $1,088 \mathrm{ppb}$ & - \\
\hline 2. & Timbal $(\mathrm{Pb})$ & $0,115 \mathrm{ppm}$ & $0,1 \mathrm{ppm}$ \\
\hline 3. & Seng $(\mathrm{Zn})$ & $0,135 \mathrm{ppm}$ & $5 \mathrm{ppm}$ \\
\hline 4. & Kromium $(\mathrm{Cr})$ & $0,032 \mathrm{ppm}$ & $0,1 \mathrm{ppm}$ \\
\hline 5. & Kadmium $(\mathrm{Cd})$ & tidak terdeteksi & $0,01 \mathrm{ppm}$ \\
\hline 6. & Tembaga $(\mathrm{Cu})$ & $0,051 \mathrm{ppm}$ & $1,0 \mathrm{ppm}$ \\
\hline
\end{tabular}

Keterangan : *) Sampel diambil Tanggal 25 November 2011.

**) Sumber Manahan (1994) dalam Achmad (2004).

Dalam penelitian ini, pengambilan sampel dilakukan pada 3 area dalam reaktor kaca yakni:

a. Area I : terletak $5 \mathrm{~cm}$ dari katoda

b. Area II : terletak $10 \mathrm{~cm}$ dari katoda

c. Area III : terletak $15 \mathrm{~cm}$ dari katoda

Pengambilan sampel dilakukan dengan selang waktu remediasi selama 3 jam, dan dilakukan sebanyak 5 kali pengambilan sampel. Sampel yang diambil sebanyak 5 gram dan dilakukan 2 kali pada tiap area namun dengan posisi berbeda. Sampel dianalisis menggunakan AAS untuk melihat konsentrasi dari tiap ion logam berat target.

Hasil Proses Remediasi Pada Konsentrasi Ion-ion Logam Berat Dalam Tanah

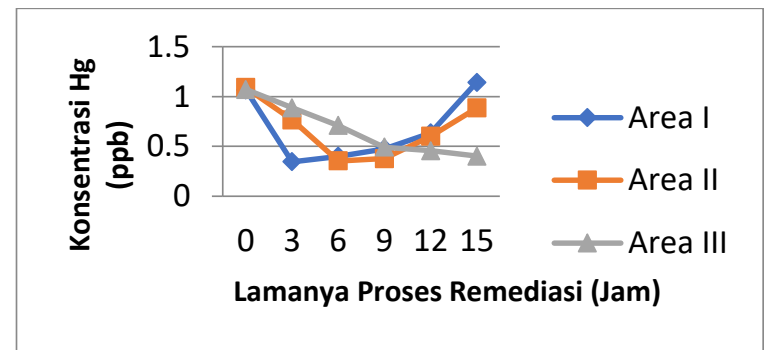

Gambar 3. Hubungan konsentrasi Hg terhadap waktu pada area I, II dan III. 


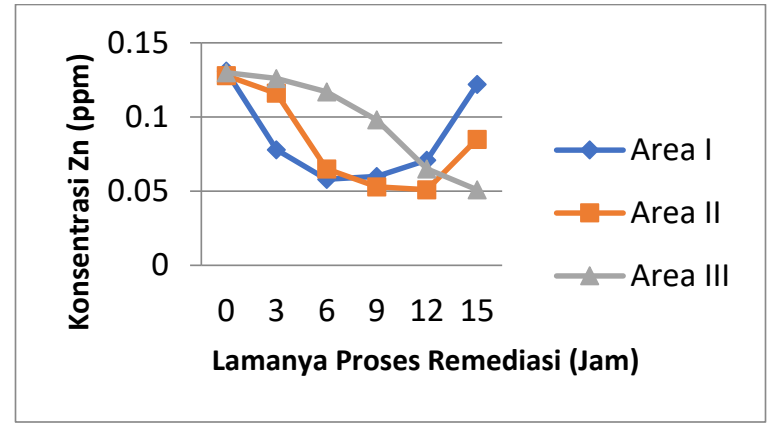

Gambar 4. Hubungan konsentrasi Zn terhadap waktu pada area I, II dan III.

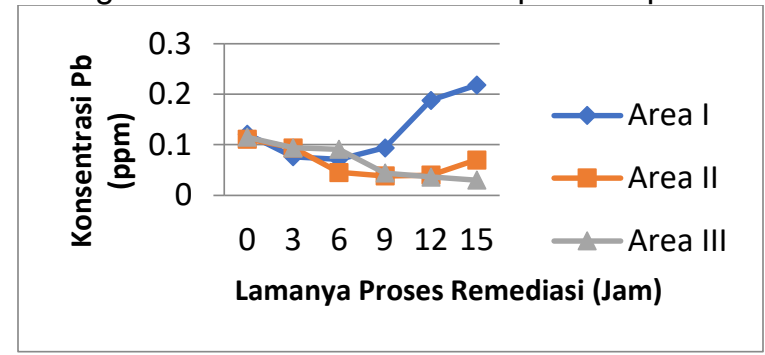

Gambar 5. Hubungan konsentrasi Pb terhadap waktu pada area I, II dan III.

mengalami penurunan konsentrasi paling besar untuk semua area pada waktu ke-3 jam proses remediasi. Proses remediasi ion logam $\mathrm{Hg}$ dari tanah terjadi hampir merata pada semua area dalam wadah tempat proses remediasi dilakukan. Hal yang serupa terjadi pada Zn (Gambar 4) dan Pb (Gambar 5). Hal ini menunjukkan adanya migrasi ionik yang terjadi selama proses remediasi dilakukan. Dimana pada daerah katoda terjadi proses reduksi air menghasilkan ion-ion hidroksil $\left(\mathrm{OH}^{-}\right.$ ) yang mengakibatkan katoda cenderung bermuatan negatif sehingga ion-ion logam tertarik pada katoda (Acar $d k k, 1990$ ). Logam yang tertarik itu kemudian diendapkan pada permukaan batang katoda. Semakin lama proses remediasi yang dilakukan, penumpukan ion logam semakin banyak. Semakin dekat titik sampling dengan batang katoda, semakin besar konsentrasi ion logam yang terdeteksi dan konsentrasi ion logam tersebut semakin meningkat pada waktu remediasi yang lebih lama.

\section{Efisiensi Proses Remediasi Elektrokinetik Untuk Mengurangi Konsentrasi Ion- Ion Logam} Dalam Tanah.

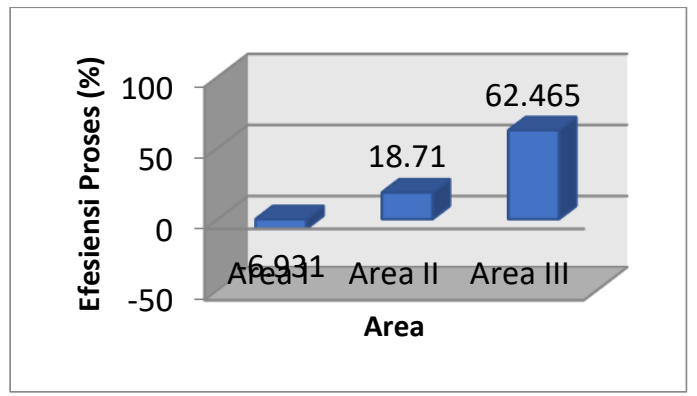

Gambar 6. Efisiensi proses remediasi terhadap kandungan $\mathrm{Hg}$ pada tiap area. 


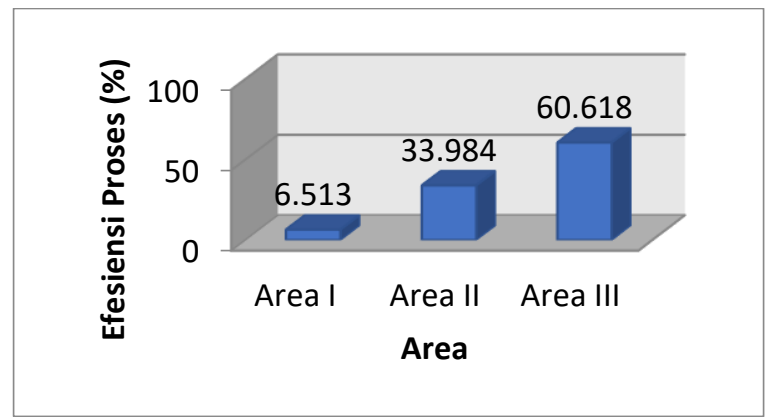

Gambar 7. Efisiensi proses remediasi terhadap kandungan Zn pada tiap area.

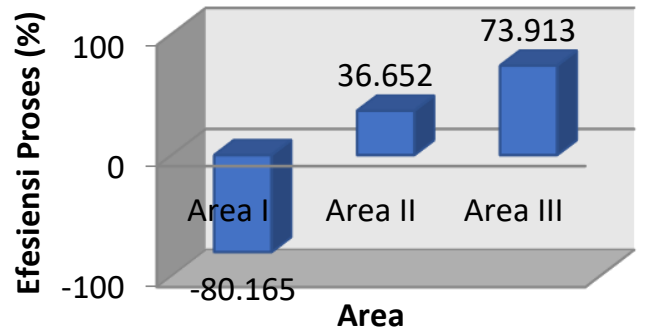

Gambar 8. Efisiensi proses remediasi terhadap kandungan $\mathrm{Pb}$ pada tiap area.

Proses remediasi tanah untuk kandungan $\mathrm{Hg}$ dapat dikatakan cukup berhasil disebabkan mencapai efisiensi proses yang cukup besar yakni 24,78\% (Gambar 6). Penurunan terbesar dialami pada 3 jam pertama. $\mathrm{Hg}$ yang terikat di katoda sebesar $0,937 \mathrm{ppb}$. Proses remediasi juga berhasil menurunkan kandungan $\mathrm{Zn}^{2+}$ dari konsentrasi awal sebesar rata-rata 0,130 ppm menjadi 0,051 ppm pada waktu ke-15 jam proses remediasi untuk area III(Gambar 7). Zn yang terikat di katoda sebesar 95,079 ppm. Secara keseluruhan nilai efisiensi penurunan $\mathrm{Zn}^{2+}$ untuk area I, II dan III masing-masing $6,51 \%, 33,98 \%$ dan $60,62 \%$. Efisiensi proses remediasi terhadap kandungan ion logam $\mathrm{Pb}^{2+}$ (Gambar 8) berfluktuasi. Untuk area I, proses remediasi efisien dilakukan pada jam ke-3 dimana nilai efisiensinya sebesar $37,60 \%$, untuk waktu yang lebih lama, nilai efisiensinya menurun. Untuk area II, proses remediasi efisien dilakukan pada jam ke-6 proses remediasi dan area III mempunyai nilai terbesar dibandingkan dengan area lainnya. Pb yang terikat di katoda sebesar 56,978 ppm.

\section{Pengaruh Proses Remediasi Terhadap pH Tanah.}

Data hasil penelitian tentang $\mathrm{pH}$ tanah pada waktu remediasi ke-0, 3, 6, 9, 12 dan 15 jam dapat terlihat pada Gambar 9. Dimana terlihat bahwa nilai pH mengalami peningkatan sejalan dengan lamanya waktu remediasi. Nilai $\mathrm{pH}$ yang semakin meningkat dari $\mathrm{pH}$ tanah awal sebesar 5,5 menunjukkan bahwa tanah bersifat asam. Peningkatan $\mathrm{pH}$ berlangsung selama proses remediasi dan menunjukkan nilai rata-rata 8,15 untuk semua daerah menunjukkan bahwa tanah menjadi bersifat basa. 


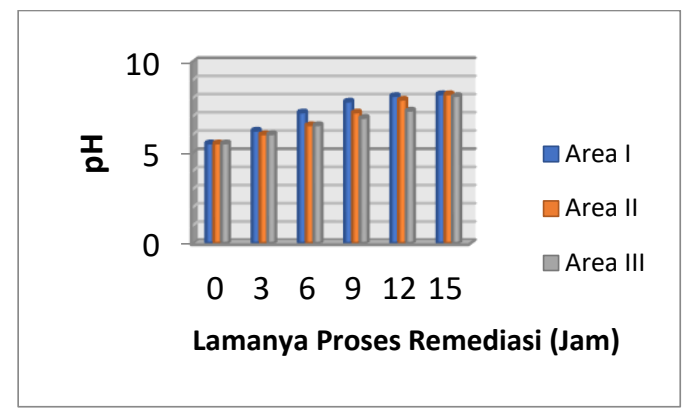

Gambar 9. Hubungan pH terhadap waktu pada area I, II dan III.

\section{Fenomena yang Terjadi Selama Proses Remediasi Tanah}

Pada awal remediasi (selama 3 jam pertama) terdapat perubahan disekitar elektroda yang terjadi \pm 5 menit setelah aliran arus dijalankan. Di katoda terdapat gumpalan coklat putih sedangkan di anoda terdapat buih berwarna putih dan kelihatan seperti air yang mendidih (Gambar 10).

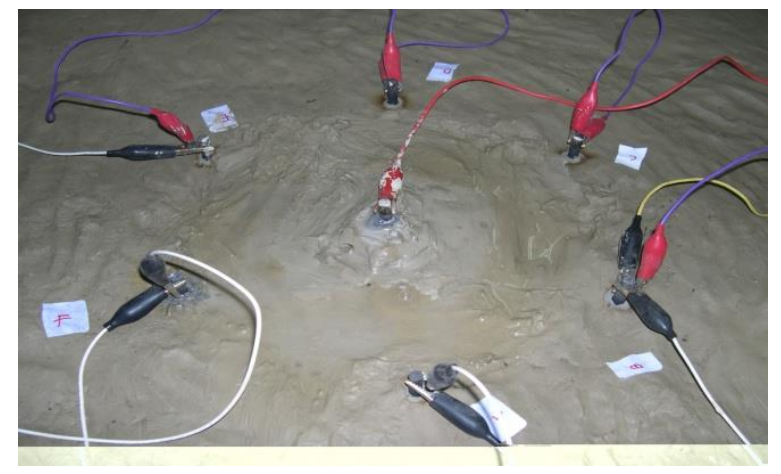

Penumpukan gumpalan terus terjadi di katoda sampai proses remediasi selesai atau waktu pengamatan ke-15 jam. Terdapat endapan yang menempel pada batang katoda sehingga batang katoda menjadi seperti besi berkarat. Sedangkan batang anoda berwarna kehitaman (Gambar 10). Gumpalan yang mengapung pada katoda itu merupakan buih yang muncul karena udara yang terperangkap dalam selaput tipis yang terbentuk dari air dan ion-ion logam. Warna merah bata atau orange atau coklat yang muncul pada permukaan tanah merupakan warna dari ion-ion logam. CdO warnanya beragam dari kuning kehijauan sampai coklat mendekati hitam, bergantung pada riwayat pemanasannya (Cotton dan Wilkinson, 1989).

\section{KESIMPULAN}

1. Dalam sample tanah dari TPA Toisapu yang diambil pada tanggal 25 November 2011 terkandung ion logam merkuri $(\mathrm{Hg})$ sebesar $1,088 \mathrm{ppb}$, Seng $(\mathrm{Zn})$ sebesar 0,135 ppm, Kromium $(\mathrm{Cr})$ sebesar $0,032 \mathrm{ppm}$, Timbal $(\mathrm{Pb})$ sebesar $0,115 \mathrm{ppm}$, dan Tembaga $(\mathrm{Cu})$ sebesar $0,051 \mathrm{ppm}$. Sedangkan Kadmium (Cd) tidak terdeteksi dalam leachate tetapi setelah dialirkan arus listrik terdapat pada endapan di katoda sebesar 1,387 ppm. Konsentrasi ion-ion logam tersebut tidak sama untuk tiap waktu karena sampah yang terdapat di TPA juga berbeda. 
2. Proses remediasi pada tanah membutuhkan waktu yang lebih lama dibandingkan dengan remediasi pada leachate karena media padat lebih sulit dilewati oleh ion logam agar sampai ke katoda.

3. Efesiensi proses rata-rata untuk $\mathrm{Hg}$ yakni $24,78 \%$, untuk $\mathrm{Zn} 33,71 \%$ dan untuk $\mathrm{Pb}$ sebesar $10,13 \%$. Dengan demikian lebih efektif untuk ion logam $\mathrm{Zn}$.

4. Efisiensi proses remediasi pada tiap jenis logam tergantung pada sifat logam itu sendiri. Tetapi secara keseluruhan untuk semua logam yang diteliti dalam penelitian ini, efisiensi proses sangat dipengaruhi oleh jarak dari katoda dan lamanya proses remediasi. Semakin dekat jarak dengan katoda, waktu yang diperlukan untuk proses remediasi semakin singkat, demikian juga semakin jauh jarak dari katoda, proses remediasi akan efisien untuk waktu remediasi yang lebih lama.

5. $\mathrm{pH}$ tanah mengalami peningkatan selama proses remediasi mengindikasikan bahwa ion positif yang terkandung dalam tanah mengalami penurunan karena diikat oleh katoda.

\section{DAFTAR PUSTAKA}

Acar, Y. B., Gale R. J., Putnam, G, A., Hamed, J. and Wong, R. L., 1990, Electrochemical Processing of Soils, Betlehem. pp. $121-130$.

Achmad Rukaesih, 2004. Kimia Lingkungan. Penerbit ANDI. Yogyakarta.

Alshawabkeh, A. N., 1999, Optimation of 2-D Electrode Configuration for Electrokinetic Remediation, Juornal of Soil Contamination, USA.

Johannes, H, 1978, Listrik dan Magnet, PN Balai Pustaka, Jakarta.

Connell.D.W dan G.J.Miller, 1995. Kimia dan Ekotoksikologi Pencemaran. Terjemahan Yanti Koestoer dan Sahati. Universitas Indonesia Press. Jakarta.

Metcalf and Eddy, 1991, Environmental Engineering Treatment, Disposal, Reuse, Mc.Graw Hill, USA.

Murck, B.W, B.J.Skiner, S.C.Porter, 1996. Environmental Geology. Jhon Wiley and Son Inc. Singapore. $535 \mathrm{p}$.

Reddy, K. R and Shirani, A. B., 1996, Electrokinetic Remediation of Metal Contaminated Glacial Tills, University of Illinois at Chicago, Chicago 